\title{
What Makes a 'Good' Ethical Leader?
}

\author{
Nanci P. Askew \\ Purdue University
}

Good ethical leaders are valued now more than ever. The COVID-19 pandemic has highlighted the importance of ethical leaders in the workplace during stressful working conditions. The best way to make sure the right type of leader is in place is to develop an understanding of what makes an ethical leader. In understanding what makes an ethical leader, existing leaders can be assessed and trained creating a safe, ethical work environment. Ethical work environments improve employee morale and fosters innovative thinking which benefits both the organization and the employees. Do ethical corporate leaders have the same standing as ethical manufacturing leaders or is ethical leadership different between the two work environments?

Keywords: ethics, leadership, manufacturing, ethical leadership, business ethics

\section{WHAT MAKES A ‘GOOD’ ETHICAL LEADER?}

Each person has their own image of what a Good Ethical Leader is. Opinions about what constitutes ethical leadership are based on life, social, and home experiences, as well as training. The Honorable Lord Moulton describes ethical behavior as something that "covers all cases of right doing where there is no one to make you do it but yourself" (La Vertu \& Barrett-Pugh, 2012, p. 5; Moulton, 1924, p. 2). Are there consistent good ethical leader character traits that are recognizable? What, if any, difference is there between a corporate leader and a manufacturing leader?

\section{LEADERSHIP}

The role of leadership has been changed by the impact that the COVID-19 pandemic has had on industry. Many workers do not want to return to work (Durbin et al., 2021) resulting in workers willing to leave or change their jobs. The media has called this 'The Great Resignation' (Dickler, 2021). It seems that "employees tend to complain less about labor violations during the [COVID-19] crisis due to fear of losing their job" and take it upon themselves to find a different job instead of staying in an environment where they are unhappy (Dirani et al., 2020, p. 383; Van Steenberg LaFarge, 1994).

This paper looks at what it takes to be a good, ethical manufacturing leader in the wake of the COVID19 pandemic. The research conducted for this paper reveals that leadership studies conducted post COVID19 pandemic focus on healthcare, supply chains, and educational institutions. The author was unable to locate significant research conducted about what constitutes a good ethical leader in the manufacturing environment. Are there differences between the ethics of manufacturing leaders and corporate leaders? 


\section{Current Issues With Post COVID-19 Leadership}

Of the leadership issues experienced post COVID-19, employee retention proves to be the greatest challenge (Hegde, 2020; Larue, 2021; Wells, 2021). While human resource development scholars consider employees "one of the most valuable assets that can lead the organization to success", workers are recognizing the abuse their employers have subjected them to during the pandemic (Dirani et al., 2020, p. 382; Hegde, 2020; Larue, 2021; Wells, 2021). As a result, many workers are willing to walk out of their jobs rather than be subjected to further abuse which impacts company turnover and morale (Hegde, 2020; Larue, 2021; Wells, 2021).

Increased unemployment benefits together with government stimulus checks have financially enabled many Americans to rethink their careers and focus on their future (DOL, n.d.; Durbin et al., 2021). Many people are choosing to find higher paying jobs and organizations that offer better benefits (Durbin et al., 2021). People are also reflecting on how hard they have worked for their employers while receiving meager pay and inadequate benefits (Durbin et al., 2021). As employees walk away from their jobs, the remaining staff is overworked as employers fail to compensate, resulting in workers who stop caring about their jobs (Durbin et al., 2021). As a consequence of employers struggling to retain staffing and employees no longer caring about the quality of the work they do, there has been a drop in customer satisfaction (Qualtrics, 2021). Even when organizations do not recognize the drop in the morale of their employees, customers can tell the employees are dissatisfied (CSP, 2017).

"Companies' ethical cultures and frameworks [act] as real-world moral compasses - helping leaders, managers, employees, and other stakeholders navigate the unforeseen and unknown" (Divers, 2021, p. 16). Because a company's culture acts as a moral compass, when a company experiences ethical fading it can spread like a cancer if it is left unchecked (Cialdini et al., 2021). Ethical fading happens in a work culture when unethical behavior is permitted or encouraged (Cialdini et al., 2021; Sinek, 2019). Ethical fading can occur in high stress situations like those generated with mandated business shut-downs caused by COVID19, lack of employer compensation, and employee walk out's (CDC, 2020; Durbin et al., 2021; Enwereuzor et al., 2020; Qualtrics, 2021; Sinek, 2019). Sinek (2019) explains that a finite mindset makes the work environment susceptible to ethical fading as employers push workers to meet their required metrics. The type of environment that pressures employees to meet performance goals (metrics) or risk losing their jobs can cause workers to resort to unethical behaviors (Sinek, 2019).

With issues like employee retention, loss of morale, and ethical fading in the workplace it is important to identify and encourage ethical leadership behaviors.

\section{Ethical Leadership Qualities}

The qualities seen in ethical leaders include virtue, integrity, authenticity, moral courage, openness, transparency, honesty, altruism, responsibility, progressive thinking, kindness, compassion, self-restraint, optimism, perseverance, and humility, just to name a few (Allal-Chérif et al., 2021; Dirani et al., 2020; Dorasamy \& Anwana, 2021; Epitropaki \& Martin, 2005; Hannah et al., 2011; Johnson, 2021; Lawton \& Páez, 2015). Ethical leaders embody a wide range of positive attributes. The motivation of an ethical leader is to make people better off (Duska, 1998).

Ethics in business is considered to be a part of Corporate Social Responsibility, however policies tend to focus on business finances in lieu of manufacturing (Berrah et al., 2021; McCann \& Holt, 2009). When leaders take ethics seriously they become more perceptive of how their decisions impact others (Lawton \& Páez, 2015). Leaders should use their authority responsibly, acting with honesty, fairness, and trust since their actions can have positive as well as negative ramifications (Dorasamy \& Anwana, 2021). "Ethical leadership has to concern ethical values" (Dorasamy \& Anwana, 2021, p. 3). Ethical leaders do not focus on themselves, they focus on the wellbeing and benefit of others (Duska, 1998). Focusing on others includes characteristics such as showing compassion for others, genuine kindness, and concern for others (Epitropaki $\&$ Martin, 2005). Because all leaders play such a fundamental role for others, behaving ethically as they support and encourage their workers demonstrates that their actions and values are aligned (Dorasamy \& Anwana, 2021; Markey et al., 2021). Hannah et al (2011) describe ethics is not just doing the right thing, but also refraining from being pressured to do something that conflicts with personal morals. 
The behavior of ethical leaders is a contrast when compared to unethical leaders. Value based behavior like integrity and honesty enforces ethical standards (Dorasamy \& Anwana, 2021). Ethical leaders believe in taking accountability and responsibility for their actions instead of blaming others (Allal-Chérif et al., 2021). Ethical leaders lead by example as they use constructive collaboration and look realistically at what is best for the group (Allal-Chérif et al., 2021). Ethical leaders utilize inclusive language (Allal-Chérif et al., 2021). Leading ethically means focusing on finding what opportunities there are for a given situation. Finding opportunities emphasizes the importance of not focusing on the problems while leading with "an attitude of moral obligation and responsibility" (Allal-Chérif et al., 2021; Dorasamy \& Anwana, 2021, p. 2). As the CBS Blue Bloods television series character Jamie Reagan says, "It's what you do next that counts," so focusing on a resolution and preventing the issue from happening again should take priority (McKay, 2012). "A true leader seeks the advantage of those being served, ensuring that self-interested conduct and conflicts of interest are addressed while performing their altruistic responsibilities" (Dorasamy \& Anwana, 2021, p. 3).

Ethical leaders look at people holistically, or as a whole, act fairly, showing genuine kindness and concern for others as they prioritize the needs of others over their own needs (Dorasamy \& Anwana, 2021; Grant, 2013; Iverson \& Varian, 1998; NSW Government, n.d.). The vulnerability and openness that ethical leaders practice fosters an atmosphere of trust helping people feel safe to speak openly (Brown, 2018; Dirani et al., 2020; Divers, 2021; Dorasamy \& Anwana, 2021; Epitropaki \& Martin, 2005; Heffernan, 2020; Johnson, 2021; Lawton \& Páez, 2015; Markey et al., 2021; Sinek, 2019). "Walking the ethical talk demonstrates commitment ... sets the boundaries and defines the direction of what has to be done, how it should be done and where one stands on the ethical platform" (Dorasamy \& Anwana, 2021, p. 3).

Markey, et al. (2021) describe how purpose, practice, and values are the dimensions of an ethical leader that create the ethical leadership framework shown in Figure 1. The ethical leadership framework displays the relationship between the leadership dimensions virtue, purpose, and practice (Markey et al., 2021). Understanding who ethical leaders are as individuals, how "ethical leaders do what they do", and why "ethical leaders do what they do" can help people better understand ethical leaders (Markey et al., 2021, p. 639). By trying to understand what virtues an ethical leader has, what an ethical leader does, and why they do it, organizations could train or teach members to fulfill leadership roles ethically.

FIGURE 1

\section{DIMENSIONS OF ETHICAL LEADERSHIP FRAMEWORK}

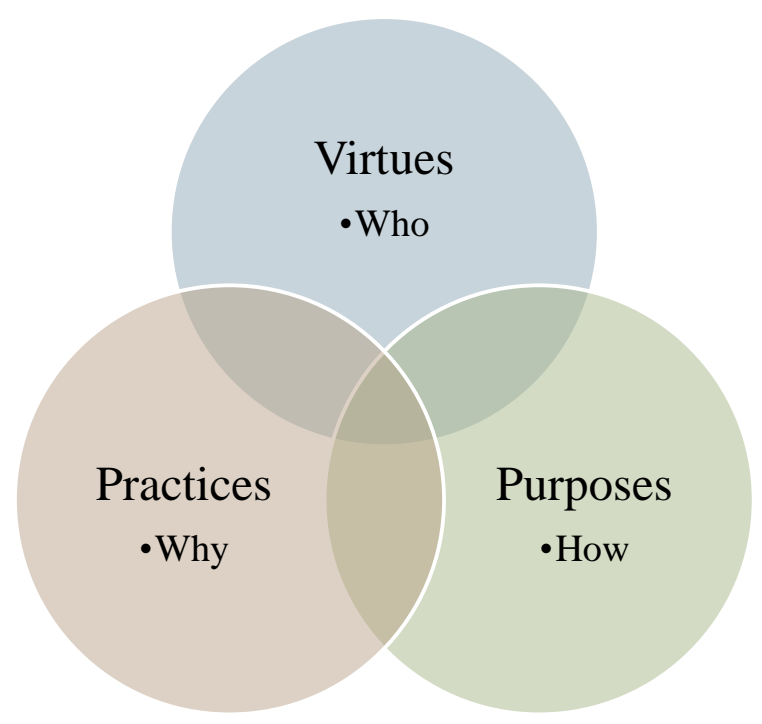

Based on (Lawton \& Páez, 2015, p. 639) 
Ethical leaders can be categorized as givers because they look for ways to do things that will benefit the most people (Grant, 2013). This type of behavior has a positive impact for others because it creates "a ripple effect, enhancing the success of people around them" (Grant, 2013, p. 10). Lawton and Páez (2015) describe leaders as something someone is, not just something someone does. Ethical leaders feel strongly that they have a duty of care to others and balance that duty of care with doing whatever they can to accomplish the "greatest good for the greatest number of people" (Dorasamy \& Anwana, 2021, p. 6). The strong ethical drive leads them to make ethical decisions in high stress situations because they feel it's their moral obligation to do so (Dorasamy \& Anwana, 2021). "When expectations like ethical conduct is violated, the fabric of society is damaged" (Dorasamy \& Anwana, 2021, p. 11).

Ethical leaders feel that fostering an atmosphere of trust is important. By behaving fairly and courteously leaders hope to create a positive atmosphere for employees. Creating a positive attitude in a work environment encourages employees to have positive responses, attitudes, and behaviors (Lawton \& Páez, 2015). When a leader's natural tendency is to show respect and treat others in a fair and dignified manner they improve an employee's performance, commitment, and loyalty to the organization. The culture created by an ethical leader promotes "authenticity, openness, and moral courage" as they lead by example in how they behave and treat others (Lawton \& Páez, 2015, p. 646). This type of culture also promotes open communication as a two-way street because it fosters trust and a feeling of safety. Feeling safe makes people feel comfortable making suggestions, challenge behavior that is inappropriate, and free to be innovative thinkers (Brown, 2018; Grant, 2013; Heffernan, 2020; Johnson, 2021; Lawton \& Páez, 2015; Sinek, 2019). Some skills that ethical leaders demonstrate include listening, being proactive, seeking to understand and cooperate, and cultivating collaborative solutions (Johnson, 2021).

Ethical leaders lead with integrity and authenticity regardless of any risks their behavior may create (Johnson, 2021). They do not follow social pressure when it contradicts personal values or could result in someone getting hurt (Johnson, 2021). The priority of ethical leaders is 'the greater good' to the extent that they will shine a proverbial light on the unethical behavior of others and blow the whistle if needed (Johnson, 2021). By getting the perspective of others, leaders can ensure that things are going well (Dirani et al., 2020).

The following are highlights of some of the qualities embodied by ethical leaders.

\section{Virtue}

Originating from Aristotle, moral virtues are the characteristics that someone has that enables them to "live a good life" (Lawton \& Páez, 2015, p. 641). Virtue is a character trait that leaders have and is seen as "moral excellence" and a "core value" (Lawton \& Páez, 2015, p. 641). These character traits include honesty, integrity, humility, compassion, altruism, enthusiasm, kindness, and responsibility just to name a few (Lawton \& Páez, 2015).

Ethical leaders display a variety of virtues depending on the leadership role they are in (Lawton \& Páez, 2015). Virtue, or moral character, is a part of ethics (Hursthouse \& Pettigrove, 2018). "Virtue is bound up in ideas of morality, offering perspectives that shape the way we live" (Lawton \& Páez, 2015, p. 641). Employees do not look at their leader as just being ethical, or having virtue, they also look at whether their leader has integrity (Lawton \& Páez, 2015).

\section{Integrity}

Finding a clear definition of integrity is difficult, however "Behavioral Integrity" is considered an action that is viewed as moral and just by society, not just an individual or organization (Lawton \& Páez, 2015; Parry \& Proctor-Thomson, 2002, p. 76). Lawton and Páez (2015) describe integrity as something someone does as well as it being something someone has; "it is both a possession and an action" (p. 642). Integrity is how a leader earns credibility because of "the perceived pattern of alignment between an actor's words and deeds" (Lawton \& Páez, 2015, p. 642). The American Psychological Association (2020) considers integrity as being honest, truthful to others as well as yourself, and morally consistent.

When it comes to leadership integrity, researchers point out that regardless of any official definition, it is the perceptions of the employees that makes the distinction (Nangoli et al., 2020). Research indicates that 
the alignment between words and deeds is what employees use to determine if a leader has integrity (Nangoli et al., 2020). The more integrity a leader is seen to consistently have, the greater the commitment and willingness the employees are seen to have by taking on more responsibilities in their job (Nangoli et al., 2020). By accepting more responsibilities, the organization benefits. In contrast, when leaders lack integrity workers are less likely to take on additional responsibilities while contributing to stress, anxiety, and dissatisfaction in their work environment (Nangoli et al., 2020). Lack of leader integrity can impact employees negatively (Boudrias et al., 2021).

\section{Authenticity}

Authenticity has a range of meanings dependent on the context of the terms use (Newman, 2019). When using the word authentic in relation to leadership characteristics, Newman's (2019) description of "Values Authenticity" is used in this paper (p. 10). Values Authenticity has also been referred to as "moral authenticity" because it is related to the observers perception as to whether it "reflect[s] sincere choices (true to one's self) rather than socially scripted responses" and "evaluate it in relation to the values and goals of the producer" because it is linked to "internal motivations" (Newman, 2019, p. 10).

When leaders act authentically this indicates they are perceived as behaving in a manner that is viewed as transparent and aligns with their personal values and beliefs (Lawton \& Páez, 2015). By contrast, a leader who is viewed as being inauthentic would exhibit the do-as-I-say-not-as-I-do attitude (Lawton \& Páez, 2015; The Holy Bible, 2016, p. Matthew 23:3).

Lawton and Páez (2015) describe authenticity as, "knowing oneself and acting transparently in accordance with one's beliefs and values, self-awareness, self-control and consistency and coherence in behaviors" (p. 642). Authentic leaders are known for their ability to coach others to become leaders, leading by example as they teach that leadership is not just about being a leader, but also about a leaders actions and behavior (Lawton \& Páez, 2015). Authentic leaders foster a positive environment, increase selfawareness, encourage self-improvement, and set aside their own interests to act in the best interest of others (Lawton \& Páez, 2015). Authentic leaders are able to "process both positive and negative self-relevant information with minimum influence of ego-defensive mechanisms" (Guenter et al., 2017, p. 10). Hanna et al (2011) describes authentic leadership as a behavioral pattern that promotes positive self-development, transparency, and an ethically positive environment.

\section{Moral Courage}

" $[\mathrm{M}]$ oral courage involves living out one's personal values even when the price for doing so may be high" (Johnson, 2021, p. 72). Hannah et al (2011) explains that moral courage is linked to not only ethical behavior but also with the environment. Figure 2 shows a graphic representation of how moral courage relates to leadership in addition to ethical and pro-social behavior. 


\section{FIGURE 2 \\ A SOCIAL COGNITIVE MODEL OF MORAL COURAGE}

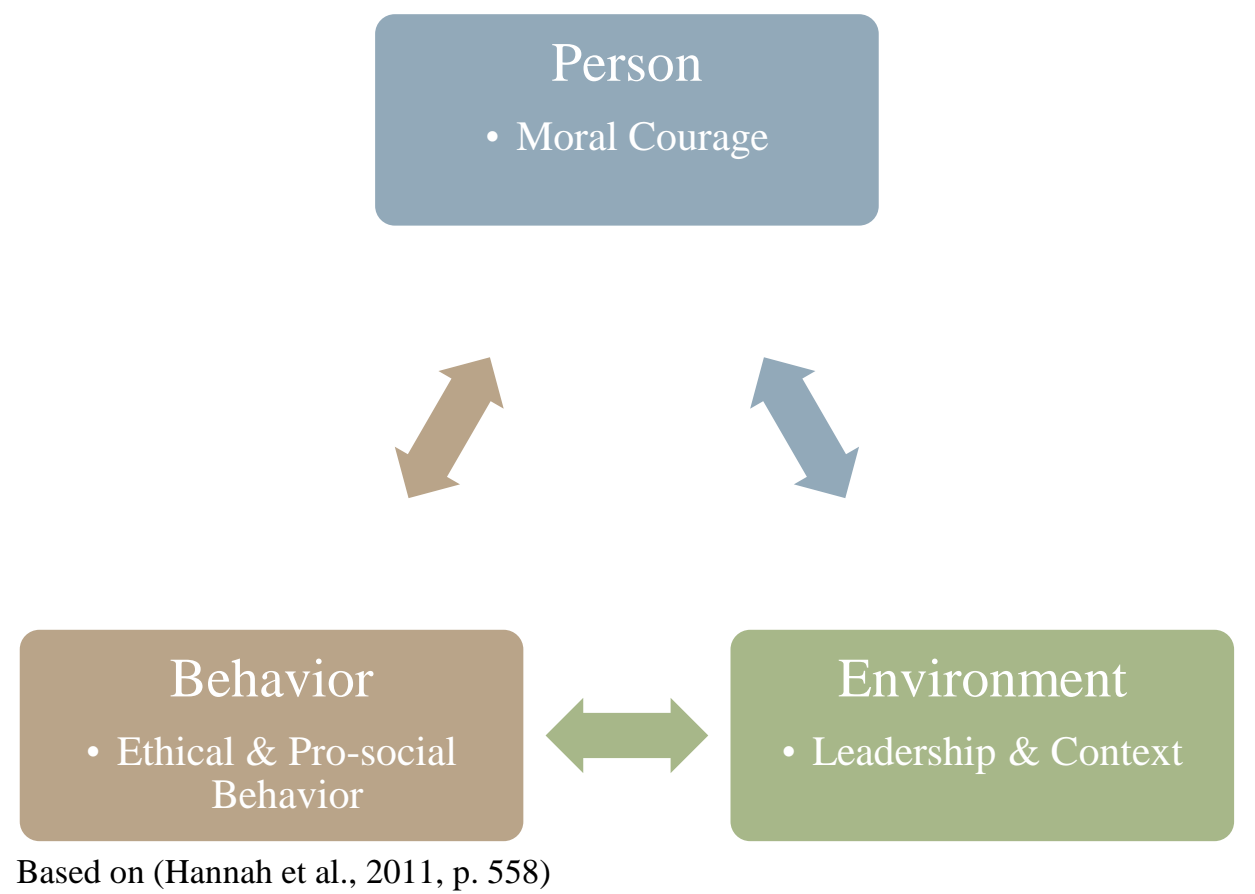

Aristotle viewed courage as acts that were repeated until they became habits, and Epictetus believed courage was not letting pressure dictate your actions (Hannah et al., 2011). Putman builds on Epictetus' definition by adding that courage goes further than not acting, explaining that failing to act could be construed as cowardice. By saying no, that you will not submit to social pressure, it "can also be an act of real courage" (Hannah et al., 2011, p. 559; Putman, 2010, p. 15). Further clarification of what moral courage means is that it can be described as a character strength (Hannah et al., 2011; Johnson, 2021).

Research indicates a positive correlation between moral courage and ethical acts as well as moral courage indicating authentic leadership and promoting ethical behavior in others (Hannah et al., 2011).

\section{Ideal Ethical Leaders}

The ideal ethical leader qualities are unique to each person because they are based on that person's beliefs and values. The way a person interprets the actions of their leaders are subjective and learned through life's experiences and preconceived notions of what attributes their ideal leader should have (Petrus, 2018; Tu et al., 2018). Ideal versions of leaders are considered inspirational as opposed to the typical leadership qualities shown by most leaders (Johnson, 2021; Petrus, 2018). The "cognitive structures of ideal leadership are stable and unaffected by experiences with leaders or other organizational factors" (Epitropaki \& Martin, 2005, p. 660).

"Impression management is integral to effective leadership because followers have images of ideal leaders called prototypes" (Johnson, 2021, p. 17). The calm confidence ethical leaders exhibit as they participate in group discussions and the ability to maintain their composure in stressful situations illustrates the integrity they value (Johnson, 2021).

Epitropaki and Martin (2005) used schema theory to understand interactions between leaders and employees they oversee (Cherry, 2019; Graziano, 2019; Schema Theory, n.d.). A schema "is a generalized description or a conceptual system for understanding knowledge-how knowledge is represented and how it is used" (Cherry, 2019; Graziano, 2019; Schema Theory, n.d.). Epitropaki and Martin (2005) explain that with implicit leadership theory, the ideal leader behavior becomes a employees benchmark standard. When an employee perceives their managers to exhibit behaviors the employee considers ideal, the better the 
quality of the leader-member-exchange, or relationship, the employees have with their manager (Epitropaki \& Martin, 2005). The closer the managers behavior aligns with the employees perceived ideal leader behaviors, the better the quality of the leader-member exchange (Epitropaki \& Martin, 2005). Leadermember exchange theory "views the dyadic relationship quality between leaders and members as the key to understanding leader effects on members, teams, and organizations" (Bauer \& Erdogan, 2015, p. 3). The relationship between leaders and employees affects employee attitudes and well-being (Epitropaki \& Martin, 2005).

Some characterizations of ideal leaders include sensitivity, intelligence, dedication, challenging existing processes, the ability to "inspire a shared vision", "encourage others to act" and follow their heart (Dirani et al., 2020, p. 381; Epitropaki \& Martin, 2005; Johnson, 2021).

The difference between the real ethical leader and the ideal ethical leader is that an ideal ethical leader is based on the preconceived notion or perception of the employee regardless of the ethics and morals displayed by the leader. The same leader could be considered ideal by one employee but not another.

\section{Bad Leader Qualities}

Characteristics that bad leaders display include not able (or willing) to use technology (incompetence), the unwillingness to work with others, or plan strategy. Bad leaders do not try to relate to others causing anger, and frustration, lowering self-esteem, overall performance, and increasing stress in their subordinates (Johnson, 2021). Some terms used to describe bad leaders are manipulative, abusive, arrogant, bossy, tyrannical, authoritative, unforgiving, destructive, despotic, dominating, and toxic (ul Haq et al., 2021)

"[W] hen non-ethical behaviors are tolerated within the organization, negative forms of leadership tend to rise and employee discretionary contributions tend to diminish" (Boudrias et al., 2021, p. 488). The behavior of unethical leaders negatively impacts the ability of those around them to reach their goals and have job satisfaction (ul Haq et al., 2021).

Unethical leaders are self-serving. They might take credit for someone else's work, be tyrannical, abusive, or aggressive. If senior leadership permits unethical behavior it can deteriorate the workers in the lower tiers in a hierarchical organization (Boudrias et al., 2021). Boudrais et al (2021) studied the impact that tyrannical managers have on their supervisors and employees. Boudrais et al (2021) found that the negative conduct of higher level management creates a cascading effect that impacts the lower level employees desire to improve at their jobs. In their research, Boudrais et al (2021) also found that if the supervisor a worker directly reports to is tyrannical (unethical), workers will look more closely at higher level management to compare behaviors. If workers see that higher level management display a desire to improve at their jobs but the worker's direct reporting manager does not it results in increased job dissatisfaction (Boudrias et al., 2021). As an organization becomes more unethical, the misconduct and moral failure increases affecting more and more people (Dorasamy \& Anwana, 2021; Grimberg et al., 2021; Lawton \& Páez, 2015).

Ethical fading, as mentioned previously, is when a culture encourages or allows unethical behavior (Cialdini et al., 2021; Sinek, 2019). Studies find that when an unethical leader leaves, the group members who remain are more likely to behave unethically highlighting the damage unethical behavior can cause (Cialdini et al., 2021). Unethical behavior that is encouraged or allowed spreads like a cancer if left unchecked. Enron was an energy company famous for an unethical accounting scandal (Silverstein, 2013; Western Governors University, 2021). Employees from Enron describe the culture within their organization as "an atmosphere of deliberately breaking rules" (Cialdini et al., 2021, p. 861). When one person breaks the rules with no repercussions, others began to imitate the behaviors, malfeasance, or deliberately doing something that is wrong or against the law, and the negative behavior becomes the new normal creating discomfort and "psychological distress" (Cialdini et al., 2021, p. 862; LII, n.d.).

Despotic leaders are considered selfish, dominating, manipulative, deceitful, self-aggrandizing, authoritative, callous, self-serving, antagonistic, exhibiting deviant behavior, considered morally corrupt, and engage in behavior that is destructive to the organization (ul Haq et al., 2021). Studies show that despotic leaders have a negative impact on the leaders, followers, and the organization as a whole (ul Haq 
et al., 2021). Despotic leaders destroy self-esteem, emotional stability, confidence, and increase tension (ul Haq et al., 2021).

\section{Manufacturing Leaders}

Manufacturing leaders need to build trust just like leaders in other industries (Putre, 2019). "[T]rust disappeared 30 years ago when companies eliminated the defined benefit pension plans that took care of loyal workers when they became too old to work" or wanted to spend time with family (Putre, 2019, p. 9). Also like leaders in other industries, in order to build trust the culture of the workplace needs to center around enthusiasm, creativity, and most of all teamwork (Putre, 2019). The trust needs to extend from the floor to the executive offices with high expectations from and for everyone. Leaders have high expectations for their workers while providing the resources for those expectations to be met and workers have high expectations for leaders to provide those resources (Putre, 2019). If one side fails to follow through the expectations of both sides will not be met. When organizations treat workers will respect it empowers workers helping to build confidence and make contributions to the company (Putre, 2019). Building confidence in workers can stoke a passion in their work. Passion drives people to think big generating moonshot ideas with innovative thinking (Putre, 2019).

\section{CONCLUSION}

Good ethical leaders have the same qualities regardless of what organization they work in. Ethical leaders treat workers ethically and show them respect, they foster work cultures where workers feel safe enough to speak openly which encourages passion, creativity, and innovative thinkers. It is mutually beneficial for both the organization and the workers to have a good, ethical work culture. The qualities of a good ethical leader are transferred to those who work with them and have a positive ripple effect throughout the organization.

\section{REFERENCES}

Allal-Chérif, O., Guijarro-García, M., Ballester-Miquel, J.C., \& Carrilero-Castillo, A. (2021). Being an ethical leader during the apocalypse: Lessons from the walking dead to face the COVID-19 crisis. Journal of Business Research, 133, 354-364. https://doi.org/10.1016/j.jbusres.2021.05.008

APAc. (2020). Integrity - APA Dictionary of Psychology. Retrieved from https://dictionary.apa.org/integrity

Bauer, T.N., \& Erdogan, B. (2015). The Oxford handbook of leader-member exchange. Oxford University Press, Incorporated. Retrieved from http://ebookcentral.proquest.com/lib/purdue/detail.action?docID=2110386

Berrah, L., Cliville, V., Trentesaux, D., \& Chapel, C. (2021). Industrial performance: An evolution incorporating ethics in the context of Industry 4.0. Sustainability, 13(16), 9209. https://doi.org/10.3390/su13169209

Boudrias, J-S., Rousseau, V., \& Lajoie, D. (2021). How lack of integrity and tyrannical leadership of managers influence employee improvement-oriented behaviors: JBE. Journal of Business Ethics, 172(3), 487-502. https://doi.org/10.1007/s10551-020-04494-5

Brown, B. (2018). Dare to lead: Brave work, tough conversations, whole hearts. Penguin Random House. CDC. (2020, February 11). Guidance for businesses and employers responding to coronavirus disease 2019 (COVID-19). Centers for Disease Control and Prevention. Retrieved from https://www.cdc.gov/coronavirus/2019-nCoV/index.html

Cherry, K. (2019, September 23). What role do schemas play in the learning process? Verywell Mind. Retrieved from https://www.verywellmind.com/what-is-a-schema-2795873

Cialdini, R., Li, Y.J., Samper, A., \& Wellman, N. (2021). How bad apples promote bad barrels: Unethical leader behavior and the selective attrition effect: JBE. Journal of Business Ethics, 168(4), 861880. https://doi.org/10.1007/s10551-019-04252-2 
CSP. (2017, July 18). Unhappy employees put your customers at risk. Retrieved from https://www.csp.com/unhappy-employees-put-customers-risk/

Dickler, J. (2021, June 29). "Great Resignation” gains steam as return-to-work plans take effect. CNBC. Retrieved from https://www.cnbc.com/2021/06/29/more-people-plan-to-quit-as-return-to-workplans-go-into-effect-.html

Dirani, K.M., Abadi, M., Alizadeh, A., Barhate, B., Garza, R.C., Gunasekara, N., . . Majzun, Z. (2020). Leadership competencies and the essential role of human resource development in times of crisis: A response to COVID-19 pandemic. Human Resource Development International, 23(4), 380 394. https://doi.org/10.1080/13678868.2020.1780078

Divers, S. (2021, May 18). How companies are stepping up efforts to build ethical cultures during COVID-19. World Economic Forum. Retrieved from https://www.weforum.org/agenda/2021/05/companies-building-ethical-cultures-covid-19/

DOL. (n.d.). Unemployment insurance relief during COVID-19 outbreak. United States Department of Labor. Retrieved from https://www.dol.gov/coronavirus/unemployment-insurance

Dorasamy, N., \& Anwana, E. O. (2021). Ethical public leadership surfing the COVID 19 terrain. International Journal of Entrepreneurship, 25(3), 1-12. Retrieved from https://www.proquest.com/scholarly-journals/ethical-public-leadership-surfing-covid19/docview/2515192453/se-2?accountid=13360

Durbin, D-A., Groves, S., Olson, A., Pisani, J., \& The Associated Press. (2021, May 18). Changed by the pandemic, many workers are reluctant to return to their old jobs. Fortune. Retrieved from https://fortune.com/2021/05/18/many-workers-reluctant-to-return-old-jobs-covid/

Duska, R. (1998). Organizational ethics and the good life, Ethical dimensions of leadership. Administrative Science Quarterly, 43(3), 713-719. Retrieved from https://www.proquest.com/scholarly-journals/organizational-ethics-good-lifeethical/docview/203956587/se-2?accountid=13360

Enwereuzor, I.K., Onyishi, I.E., Albi-Oparaocha, F.C., \& Amaeshi, K. (2020). Perceived leader integrity as a mediator between ethical leadership and ethical climate in a teaching context. $B M C$ Psychology, 8, 1-11. https://doi.org/10.1186/s40359-020-00420-6

Epitropaki, O., \& Martin, R. (2005). From ideal to real: A longitudinal study of the role of implicit leadership theories on leader-member exchanges and employee outcomes. Journal of Applied Psychology, 90(4), 659-676. https://doi.org/10.1037/0021-9010.90.4.659

Grant, A.M. (2013). Give and take: Why helping others drives our success. Penguin Books.

Graziano, M.S.A. (2019). Attributing awareness to others. Journal of Consciousness Studies, 26(3-4), 21. Retrieved from https://www-ingentaconnectcom.ezproxy.lib.purdue.edu/content/imp/jcs/2019/00000026/f0020003/art00002\#Supp

Grimberg, N.E., McManigle, J.E., \& Barry, E.S. (2021). Identifying, understanding, and handling bad, ineffective, and toxic leaders and followers. Journal of Leadership, Accountability and Ethics, 18(1), 68-75. Retrieved from https://www.proquest.com/scholarly-journals/identifyingunderstanding-handling-bad/docview/2512177791/se-2?accountid=13360

Guenter, H., Gardner, W.L., Davis McCauley, K., Randolph-Seng, B., \& Prabhu, V.P. (2017). Shared authentic leadership in research teams: Testing a multiple mediation model. Small Group Research, 48(6), 719-765. https://doi.org/10.1177/1046496417732403

Hannah, S.T., Avolio, B.J., \& Walumbwa, F.O. (2011). Relationships between Authentic Leadership, Moral Courage, and Ethical and Pro-Social Behaviors. Business Ethics Quarterly, 21(4), 555578. https://doi.org/10.5840/beq201121436

Heffernan, M. (2020). Uncharted: How to navigate the future. Avid Reader Press.

Hegde, A. (2020, December 7). Humanised HR - The calming effect on employee relations in postCOVID world. Business World, NA. Gale OneFile: Business. Retrieved from https://link-galecom.ezproxy.lib.purdue.edu/apps/doc/A644009656/GPS?u=purdue_main\&sid=bookmarkGPS\&xid=87045bd6 
Hursthouse, R., \& Pettigrove, G. (2018). Virtue ethics. In E.N. Zalta (Ed.), The Stanford Encyclopedia of Philosophy (Winter 2018). Metaphysics Research Lab, Stanford University. Retrieved from https://plato.stanford.edu/archives/win2018/entries/ethics-virtue/

Iverson, K., \& Varian, T. (1998). Plain talk: Lessons from a business maverick. Wiley.

Johnson, C.E. (2021). Meeting the ethical challenges of leadership; casting light or shadow (7th ed.). Sage Publishing.

La Vertu, E., \& Barratt-Pugh, L.G. (2012). Ethical Dilemmas during mergers, acquisitions and takeovers. Proceedings of Australian and New Zealand Academy of Management (ANZAM) Conference, p.15. Perth, Australia. ANZAM. Retrieved from http://ro.ecu.edu.au/cgi/viewcontent.cgi?article=1108\&context=ecuworks 2012

Larue, B. (2021). COVID-19 and labor issues: An assessment. Canadian Journal of Agricultural Economics/Revue Canadienne d'agroeconomie, 69(2), 269-279. https://doi.org/10.1111/cjag.12288

Lawton, A., \& Páez, I. (2015). Developing a framework for ethical leadership. Journal of Business Ethics, 130(3), 639-649. Retrieved from http://www.jstor.org.ezproxy.lib.purdue.edu/stable/24703528

LII. (n.d.). Malfeasance [Law University]. LII / Legal Information Institute. https://www.law.cornell.edu/wex/malfeasance

Markey, K., Ventura, C.A.A., Donnell, C.O., \& Doody, O. (2021). Cultivating ethical leadership in the recovery of COVID-19. Journal of Nursing Management, 29(2), 351-355. https://doi.org/10.1111/jonm.13191

McCann, J., \& Holt, R. (2009). Ethical leadership and organizations: An analysis of leadership in the manufacturing industry based on the perceived leadership integrity scale. Journal of Business Ethics, 87(2), 211-220. Retrieved from http://www.jstor.org.ezproxy.lib.purdue.edu/stable/40294917

McKay, J. (2012, March 9). Blue Bloods (Season 2, Episode 17) [MPEG4-Video File]. In Reagan v Reagan. CBS.

Moulton, H.L. (1924). Law and manners. The Atlantic Monthly, 134(1). Retrieved from http://www2.econ.iastate.edu/classes/econ362/hallam/NewspaperArticles/LawAndManners.pdf

Nangoli, S., Muhumuza, B., Tweyongyere, M., Nkurunziza, G., Namono, R., Ngoma, M., \& Nalweyiso, G. (2020). Perceived leadership integrity and organisational commitment. The Journal of Management Development, 39(6), 823-834. https://doi.org/10.1108/JMD-02-2019-0047

Newman, G.E. (2019). The psychology of authenticity. Review of General Psychology, 23(1), 8-18. https://doi.org/10.1037/gpr0000158

NSW Government. (n.d.). What is a holistic approach? - Principles for effective support. Retrieved December 2, 2021, from https://www.health.nsw.gov.au/mentalhealth/psychosocial/principles/Pages/holistic.aspx

Parry, K.W., \& Proctor-Thomson, S.B. (2002). Perceived integrity of transformational leaders in organisational settings. Journal of Business Ethics, 35(2), 75-96. Retrieved from http://www.jstor.org.ezproxy.lib.purdue.edu/stable/25074659

Petrus, A.A. (2018). Construct validity of the ideal implicit leadership theories and implicit followership theories. Psihologia Resurselor Umane, 16(1), 4+. http://dx.doi.org.ezproxy.lib.purdue.edu/10.24837/pru.2018.1.482

Putman, D. (2010). Philosophical roots of the concept of courage. In C.L.S. Pury \& S.J. Lopez (Eds.), The psychology of courage: Modern research on an ancient virtue (pp. 9-22). https://doi.org/10.1037/12168-001

Putre, L. (2019, February 7). What makes a great manufacturing leader? IndustryWeek. Retrieved from https://www.industryweek.com/leadership/article/22027110/what-makes-a-great-manufacturingleader

Qualtrics. (2021, November 16). Global consumer trends in 2022. Retrieved from https://www.qualtrics.com/blog/global-consumer-trends-2022/ 
Schema theory. (n.d.). Sacramento State University. Retrieved from https://www.csus.edu/indiv/g/gipej/teaparty.pdf

Silverstein, K. (2013, May 14). Enron, ethics and today's corporate values. Forbes. Retrieved from https://www.forbes.com/sites/kensilverstein/2013/05/14/enron-ethics-and-todays-corporatevalues/

Sinek, S. (2019). The infinite game. Penguin Random House.

The Holy Bible (Thinline). (2016). Good News Publishers.

Tu, M-H., Bono, J.E., Shum, C., \& LaMontagne, L. (2018). Breaking the cycle: The effects of role model performance and ideal leadership self-concepts on abusive supervision spillover. Journal of Applied Psychology, 103(7), 689-702. https://doi.org/10.1037/apl0000297

ul Haq, M.A., Ahmed, M.A., Shabeer, S., \& Khalid, S. (2021). Effect of despotic leadership on counterproductive behavior: The role of reduced organization-based self-esteem and emotional stability. Revista Brasileira de Gestão de Negócios, 23(3), 454-469. https://doi.org/10.7819/rbgn.v23i3.4116

Van Steenberg LaFarge, V. (1994). The ambivalence of departing employees: Reactions of involuntary and voluntary exiters. The Journal of Applied Behavioral Science, 30(2), 175-197. https://doi.org/10.1177/0021886394302003

Wells, A. (2021, May 3). Returning to work after COVID workers' comp in a post-COVID world. Insurance Journal, NA. Retrieved from https://link-galecom.ezproxy.lib.purdue.edu/apps/doc/A660477950/GPS?u=purdue_main\&sid=bookmarkGPS\&xid=594a6827

Western Governors University. (2021, March 2). Ethical dilemmas: How scandals damage companies. Retrieved from https://www.wgu.edu/blog/ethical-dilemmas-how-scandals-damagecompanies 1909.html 